\title{
FORMULATION OF SUSTAINABLE AGRO FORESTRY MODELS FOR NORTH CENTRAL DRY ZONE OF SRI LANKA
}

\author{
U. Lakshman' \& D.M.S.H.K. Ranasinghe2 \\ 1 Department of Agriculture \\ 2 Department of Forestry \& Environmental Science, \\ University of Sri Jayewardenepura
}

Increase of human population and clearing of forests for their requirements has been a local as well as global environmental crisis. In Sri Lanka, forest cover has dwindled at an alarming rate from $70 \%$ in 1990 to $22 \%$ as of present. Deforestation and degradation of land due to many reasons including poverty related land management practices such as shifting cultivation and forest encroachments, conversion of forest estate to other more economically profitable land uses are some of the reasons for the loss of forest. agroforestry has been identified all over the world as an appropriate alternative which provides sustainability.

According to the Forestry Sector master Plan (1995) the necessity of utilizing the sparsely . used scrub lands for agroforestry venturcs to improve the tree cover and socio-economic status of the people has been identified. Forest Department too in its Participatory Forestry Project has ventured into establishment of farmers woodlots with the active participation of communities and this programme is wide spread in many parts of the country especially in the dry zone. However, the composition of these farmers woodlots still not complete to incorporate diversity and sustainability. Therefore, the objective of this present study is to formulate sustainable tree-crop models for a wide range of land classes in the north central dry zone of Sri Lanka.

Ipalogama divisional Secretariat in Anuradhapura District was identified for the study. Field studies were done in handsomely selccted 3 traditional tank based villages namely Sangattewa, Puliyankulama and Dampeleassagama . Information was gathered through a questionnaire survey, field visits and personnel interviews with villagers. Randomely selected 44 households or $14.8 \%$ of the total households in the 3 villages were subjected to 
the survey. The species composition and vertical and horizontal diversity, light requirements, multiple uses, financial returns/ha, prevalence of local/indigenous tree species and farmer's choice were taken into consideration in the formulation of the agroforestry models for the various land classes sampled eg. Alluvial plains, middle slopes and upper slopes etc. 